\title{
The concept of sustainable development in spatial management of mountain settlement units
}

\author{
Anna Wojtas-Harań ${ }^{1, *}$ \\ ${ }^{1}$ Departament of Architecture, Housing, Industrial, Interior, Rural Planning, Landscape, Visual Arts, \\ Faculty of Architecture, Wrocław University of Science and Technology, Poland
}

\begin{abstract}
Relationship between the built environment and nature is particularly noticeable in areas with valuable natural assets. The special physiographic conditions over there often initiate the development of towns, becoming even the impetus for the new, modern settlement. Many times the environmental advantages, paradoxically turn into theirs doom. Building imprints mark. Initially, it becomes the model complement with the natural world, until it does not exceed the difficult to define boundaries. The aim of this thesis is to search for solutions that will allow for spatial sustainability between the built and natural environments of the Karkonosze. The attractive mountain area used for sports and tourism now meets with the processes of urbanization. These issues are subject to analysis by the use of comparative method providing the different concepts of towns located in the high mountain areas of Austria. Described resorts with well-developed ski and tourism infrastructure can be examples of saving the scale and unique character, despite growing new needs and expectations of tourists and athletes. There is a chance to evolve their own local standards for space use in the Karkonosze. Key findings relate inter alia the size and the level of density of the villages. Because they affect the possibility of maintaining a proper relationship between man and nature. The issue of protection and use of historical complexes in the context of efficient space management is not without a significance.
\end{abstract}

\section{Sports tourism - a problem or a benefit}

Natural environment delights, inspires, motivates. Artists share the fascination in nature with pen and brush. Engineers overcome the forces of nature and technical limitations more or less beautifully integrate their works into the richness of forms of nature. For many, it is a place of rest, activity, recovery, and vitality. All this makes the environment attractive.

The popularity of mountain areas as a destination has increased in the nineteenth century. The educational tours of Europe, for artists and young aristocrats, culminated in the exploration of the Swiss landscape. One of the oldest objects dedicated primarily to tourism come from Switzerland - the "land of landscape journey." The first hotels appeared in the most beautiful spots of the Alpine landscape. Initially, the individual investments

* Corresponding author: anna.wojtas-haran@pwr.edu.p1 
perfectly complemented the unspoiled mountain scenery. It was a relationship of natural and built environment planned deliberately. Nature rewarded those who have escaped from the city seeking freedom, loneliness, simplicity, romanticism. Some perceive an internal distance in the first period of taming these two environments. The architecture of the first eighteenth century' objects in the classicist convention or later representative suburban villas contrasted with the surroundings. The gradual colonization of the mountains, however, led to the discovery of folk forms and their duplication. Rustic forms (in "Swiss style") were prevailing. In particular, this ornate building direction, based on the wooden, Swiss, countryside construction, was disseminated and continued to become an "international style phenomenon." The enchantment of an immense, mountain landscape, which awakened on the one hand, and on the other gave a sense of security, encouraged the incorporation of landscaping into the buildings. Through the proper orientation and positioning of the building, the window frame became part of the living room. Loggias and balconies, terraces, bay windows, had the effect of prolonging the lounges by penetrating into the mountain landscape. "Nature has become an ornament" [1]. It was still "refined" by designing idyllic, alpine, landscaped gardens in surroundings of the buildings. The ideal was the English park establishment in which naturalness, cohesion with the landscape and mood-sentimental atmosphere played the most important role in the arrangement. At the beginning of the nineteenth century, the spa traditions also resurrected. Sports and physical recreation began to develop more intensively. Hygiene, climatotherapy, heliotherapy, thalassotherapy spread out. Modern climate treatments got around in all the esteemed medical institutions in Europe. The natural environment of the mountains was a favorable place for treatment with fresh air, sun, including as well diets and physical therapies: massage, inhalation, electro, radio, thermal, hydro, motility - therapies. It was fashionable to enjoy the benefits of fresh air, climate, bathing, the sun, nature, and countryside, contributing to new social practices, a new lifestyle. It was manifested in the care for greenery and sports grounds, walking trails. Newly constructed or modernized highaltitude hotels and spa facilities offered sports facilities such as swimming pools, playgrounds, gyms, promenades, sports fields. It was the discretion purposes only that cure houses` architecture did not differ from that which was typical for hotels. However gradually some spa architecture has begun to be featured by details like largely glazed loggias, deep balconies, glass facades, becoming recognizable.

The next stage in human-environment relations was the discovery of mountain nature in winter. Norwegian Fridtjof Nansen spread it among others, using skis. In 1888 he crossed Greenland skiing. Skiing has provided an opportunity for intensive, physical activity in connection with wandering in the wild, giving joy that contrasted so much with "the melancholy of urban civilization" [2].

From the beginning of the twentieth century, the development of the winter tourism has made poor, agricultural and mountainous regions prosperous and bankrupt hotels leaped from bankruptcy. Skiing was an ideal symbiosis of sport and tourism in the experience of mountain nature. It is claimed that no other activity, like skiing, has so much to do with the landscape and has left so much of the region's culture [3]. Ski regions developed through sport and tourism infrastructure. The first sports equipment were often carefully integrated into the terrain topography. At the same time, the elements of castle architecture, decorative secession, a period of historicism, which combined perfectly with forest parks or rocky mountains, were common in the construction industry. All they created extensive architectural, park and landscape concepts.

In the twentieth century, opinions on the positive impact of sport continued and evolved. Skiers have seen themselves as pilgrims who have chosen the nature of the winter mountains as their destination [4]. The hunger of the air, the sun, the water, the snow and the "tan" was touching individuals tired and stressed by civilizations. However, this cultural need, 
according to many, has nothing to do with pioneering aspirations. Interest in the convenience of life has led the urban habits of building to the countryside. The newer resorts were erected higher, over the valleys, renowned resorts. At present, the first winter sports centers in Switzerland, such as Davos or St. Moritz, are now large-scale spas, with plenty of urban splurges, including contrasts between old and new.

The wave of return to the sources, i.e., the delight of the unpolluted, mountain environment and the desire for direct contact with nature and authentic native country architecture, has repeatedly returned in the twentieth century, up to modern times. In the $20 \mathrm{~s}$ of the twentieth-century, new sports centers were built on the ground of mountain villages the so-called first generation stations (Megeve, Chamonix). The first tourist constructions inspired local architecture. After the Second World War, mountain colonization programs developed for skiers. The ski stations were created on a rough root in highland pastures (Courchevel) according to the concept of development respecting the environment. In the 70s of the twentieth century, after the period of unstoppable expansion of the mountains, again the stations were established, which were in line with the concept of harmonized tourism, in synergy with the needs of the local community. Nowadays the resorts that correspond to traditional villages formed ex nihilo or based on existing settlements (e.g. Gstaad, Verbier, Grindelwald, Appenzell) are becoming popular again. More than two centuries of the development of winter sports and the expansion of tourism and sports construction have caused some regions of Europe to experience the problem of urbanization.

The Alps are the most invested mountain chain in the world. There is a general awareness that the level of investments reached the highest level. Other mountain ranges like the Tatry, the Sudety are also at risk of urban development. In parallel, the concern of the environment and sustainability is growing. Some towns famous for their healthy climate and mountain air, are now experiencing a smog alarm.

The beginnings of wandering tourism, followed by winter sports, especially skiing, were associated with the fascination of the mountains. It was young and sincere. The lack of adequate infrastructure, comfort or effort that accompanied the exploration of mountainous terrain was not so painful for the opportunity of experiencing and feeling the nature. However, the magical alpine huts were replaced by the exclusive hotels, the white solitude of mountains - by overflowing resorts. The development of sports and tourism has turned into a mass movement, and mountain settlements - into in cities at altitude. However, there are areas, which for various reasons managed to maintain a balance between the nature of the place, the natural environment and the growing needs and expectations of tourists and athletes.

\section{Szklarska Poręba - the settlement scattered in the landscape}

In 1366 the existence of a settlement on the slopes of the Karkonosze was recorded. Glassmaking and intensive logging contributed mainly to its development.

The beginnings of tourism in the region of Szklarska Poreba, connected with the discovery of the highest, largest and most pictoresque massif of the Sudetes, date back to the seventeenth century' expeditions to Kamieńczyk Waterfall [5]. The construction of the road from Piechowice to Huta Józefina in Szklarska Poreba in 1849 and the opening of the railway line in 1902 connecting Piechowice and Harrachov were great importance for the expansion of the tourist traffic.

At the turn of the nineteenth and twentieth century, there was a tendency of construction, coupled with the sports and tourist movement, which changed the landscape of the Karkonosze. Villages, hamlets and highland areas, including Szklarska Poręba, were filled with a magnificent architecture of tourism, recreation, and health facilities. There were pensions, hostels, hotels, villas, sanatoriums. Most of the buildings come from this period, 
which constituted the Spa and urban character of the village. The landscape of the majestic mountains, which originally co-created the architecture of the Sudeten hut, has enriched the romanticism of the headquarters for those who seek contact with mountain wildlife. Already in 1837, the first object was erected in the Karkonosze - the shelter above Śnieżne Kotły dedicated to tourists [6]. At first, the existing buildings of rural farms grew up and were rebuilt. Different solutions were applied to obtain light, sun and contact with nature and landscape: adding viewing balconies, verandas, terraces, adapting the attic for residential purposes, enlarging window openings, introducing new large plane of windows. At the same time, efforts were made to preserve the regional, rural character of buildings.

After 1870, hotels and inns in the style of the big city began to appear. It has been criticized in particular by people related to culture [7]. They were of the opinion that the erected objects should refer to the landscape and the current construction methods. However, it did not affect at all the aesthetic preferences of villa suburban's supporters. Villas represented a repetitive repertoire of forms referring to the motifs of historical architecture such as projections, mansard roofs, towers, smooth lines of window openings, doors, sometimes also roof eaves. The use of material: the rough granite of plinths, terraces, or loggia constructions and possibly the wood of roofs were the only reference to local traditions.

However, in general, the architectural image of the village has been dominated by forms inspired by Swiss, Gothic, Neo-Gothic, wooden and regional architecture. Ideas of vernacular art continued until the Second World War. Nevertheless, at the end of this era, often found the homeliness on a monumental scale, devoid of finesse, did not deliver such a romantic impression at all.

Except of the centre, and thus of the main street of the village, the buildings were erected on large plots, often naturally corrugated, far from the road, and in some cases far from the centre, on the surrounding meadows, at the edge of the forest. The natural and scenic values of the newly appropriated virgin areas were highly appreciated. Numerous streams and lakes swayed between the parcels. The trails are present on old maps and photographs. The natural slope of the terrain was adapted to the buildings using artificial scarps. The greenery of park complemented the landscaped model of the urban layout.

There were also sports and recreation areas in the surroundings: ski and toboggan runs, bobsleigh runs, ski jumps, ski lifts, tennis courts, swimming pools, ice rinks. They usually used natural predispositions of the site: topography, water, flora, allowing only minimal interference with the environment. The majority of these facilities were open-air, making up a favourable balance of green spaces in the estate.

The penetration of the natural environment into individual districts and possessions: varied forest flora, expressive rock forms typical for the Karkonosze Massif, was the characteristic feature of the village. The consequence of such practices is the loose, freely spaced, yet the orderly structure of Szklarska Poręba (fig.1).

Over time, some open areas have lost their original shape or have been built up. Cubature objects of a scale not compatible to existing buildings arose in the green spaces or the areas dedicated to the public greenery associated with the sport. After more than two centuries of the intense development of sport and tourism, the harmony between the built and natural environment has staggered. 


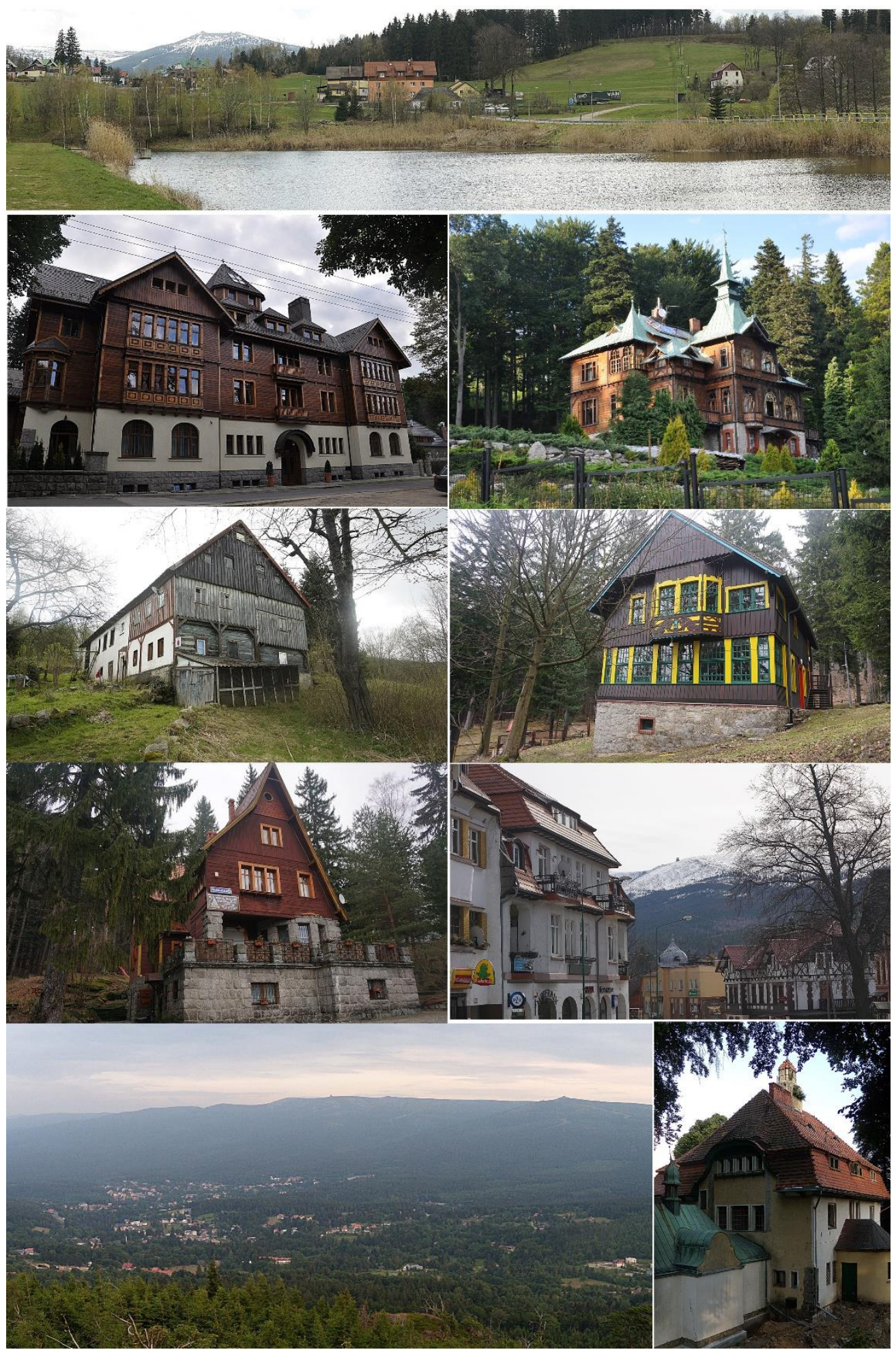

Fig. 1. Szklarska Poręba 2017 (photos by author). 


\section{Semmering - the monumental landscaped park}

The origin of Semmering (fig. 2) was the Semmering hotel (Südbahnhotel) from 1882 in a highland village, on the railway line from Vienna to Trieste. The hotel was built according to the formula of the first Swiss mountain hotels [8]. For many consecutive years, it was expanded and rebuilt to compete for the first place among the most luxurious hotels. However, earlier it was a miracle of engineering - the railway opened in 1854, bringing the first tourists to the Eastern Alps and the Semmering Pass. These two investments have given rise to other tourism and sports projects and the unique, representative architecture.

Quarters for the villa colony were located around the hotel. Designers tried to achieve the harmony with nature by designing homes in the form of farms. The first example of traditional landscape architecture was the Schönthaler villa, erected in 1882, and further various houses based on Tyrolean and eastern Swiss huts. The ideals of the promotion of the rural forms, however, were overbalanced by the fashion for splendid villas that served the purposes of the recreation of their owners and as a source of income. Buildings of the forms copied from the style of the past epochs have dominated the developers' habits.

As a result, there was built an exclusive residential area. In the following years, magnificent the Grand Hotel Panhans (1888) and the Kurhaus (1909) were erected. The Südbahnhotel underwent the biggest phase of expansion in 1913, which turned into a fairytale castle. The Silberer Schlössl, founded in 1894, was a symbol of glamor. The miniature version of the castle Neuschwanstein owes its impressive figure due to numerous stylized details of Gothic and Romanesque. Turrets, bay windows, lancet windows, battlements, solid hip roofs, diverse plans are features that have existed in this type above mentioned buildings. They seemed to be the best correlation with mountain nature.

Since 1900 architects have tried to get free from the ornament of replicas of historicism. That was the way, the Villa Landau (1908) and the Villa Löwy (1910) came into being under the influence of Art Nouveau (Jugendstil). The Villa Löwy's cubic form, with a frugal decoration, even ran out to the future - to a modern, unadorned aesthetic ornament. The Villa Khuner (1930) was an attempt to refer to rural buildings in a modern, modernist way and reap the value of the natural environment by opening to the sun and views. Despite the sometimes stylistic diversity, a coherent whole came out.

The resort stretched out, now similarly, along with the eastern slopes of the Pinkenkogel. The representative buildings stretch along Hochstraße, which connects the Grand Hotel Panhans and the Südbahnhotel, like two poles. A few hundred meters downstream, the railway line intersecting tunnels and viaducts, concentrates the remainder of the estate. The buildings were planned at a considerable distance from each other, with panoramic views of the surrounding mountain ranges, amidst wooded hills. Although the architecture of erected buildings would point to urban connotations, it was not allowed the urbanization process to take over the neighbouring nature.

The resort was once described as Austrian St. Moritz, due to the number of winter sports practiced here. The first toboggan runs were laid out along the streets. Sports facilities were associated with the tourist infrastructure. They formed with large green complexes - sports and entertainment parks. The Bobsleigh track, the ski jump, the skating rink, the lift and the park grounds were next to the Hotel Erzherzog Johan and the toboggan run and the swimming pool more near the Hotel Panhans. The Südbahnhotel offered the experimental park of experience: the toboggan runs, the tennis courts, the children's playground, the rides, crickets, golf, gliding grounds. A network of diverse secluded paths and roads separated various recreational and sports areas. In composing the premise, there were rules of the seventeenth century' landscape parks that introduced freedom, naturalism, and romanticism. Natural rocks and plant formations were naturally preserved and combined with garden architecture. At present, the complex in its original shape does not exist. 


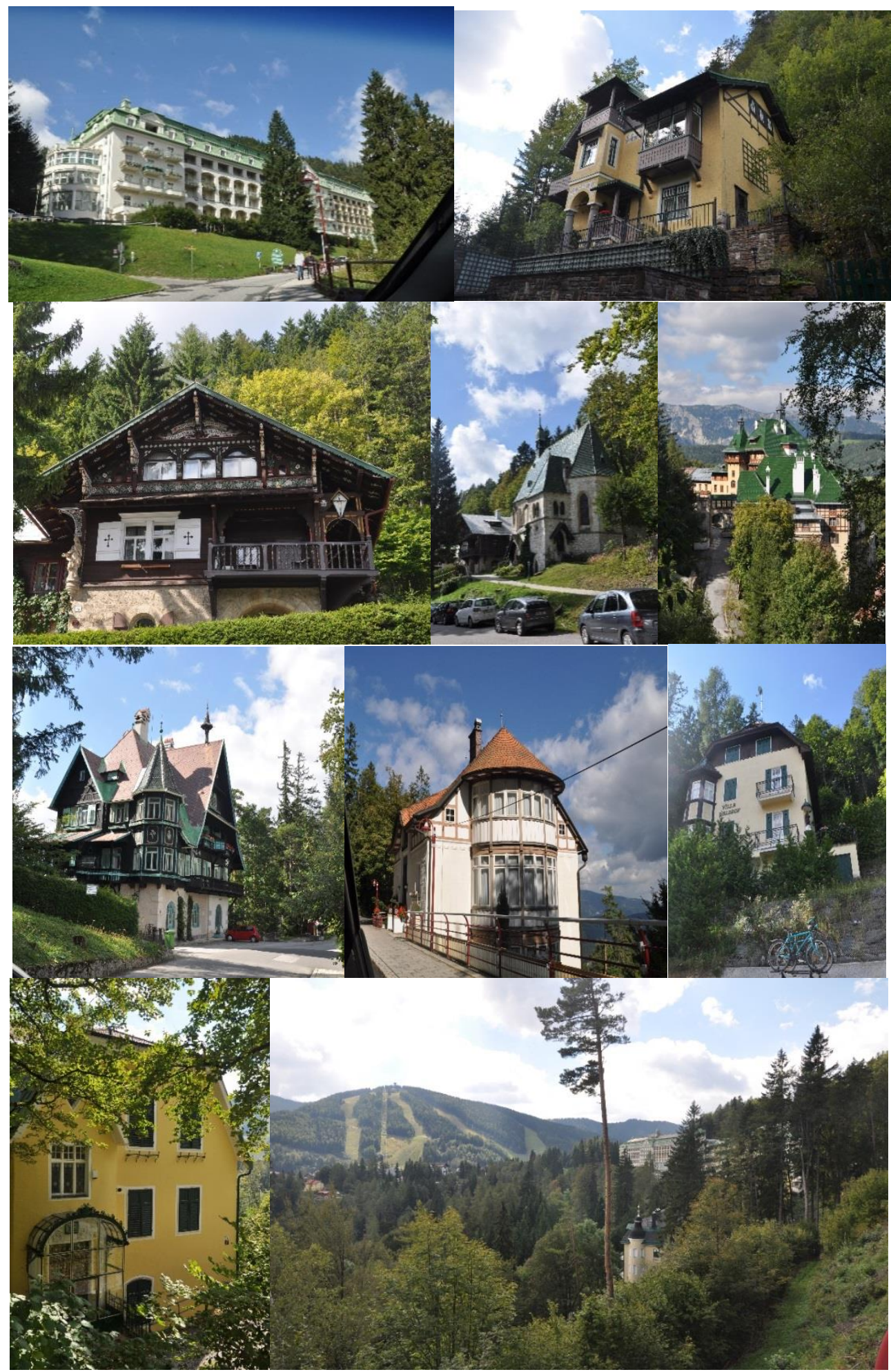

Fig. 2. Semmering 2016 (photos by author). 
There are the trails of roads, walls, groves, ponds and stone sculptures that have remained. There is also the mysterious atmosphere of the place that formerly was changing into a winter sports paradise.

In the post-war years, the town expanded in a well - connected zone thus the area of the Semmering Pass and Hirschenkogel. The resort provided modern lifts and snowmaking system, service infrastructure. With exception to the historical part, many modernizations were introduced. The proportions between the natural environment, the old building ,tissue" as well as the new infrastructure are in balance.

\section{Natural world of Sankt Anton am Arlberg and the surrounding area}

In the winter season 2016/2017, resorts: Zürs, St. Christoph, Sankt Anton am Arlberg (fig. 3), Stuben, Lech, Schröcken, Warth came together in one ski area - "Ski of Fame" due to the culminating node. The network of modern cable cars and lifts allow to reach the highest mountains of the world, over 2000 m.a.s.l. and moreover, up to each of the above locations.

Excellent ski conditions, guaranteed snow, innovative sports, and tourism infrastructure, beautiful nature attracts and gathers crowds of enthusiasts of active outdoor lifestyle. Despite the influx of visitors, the above-mentioned villages have maintained exceptional calm and moderate development area compared to other modern ski resorts. Although in the early decades of the twentieth century, too many people were complaining about too much crowding, noise, crowds of inauthentic tourists.

Sankt Anton am Arlberg is located at the Arlberg Pass. Ancients already knew the route through the pass. It was effortful and dangerous. In 1386 the first shelter was erected at the top of the pass. However, the Bregenz to Innsbruck railway (opened in 1884) started the tourist and sports expansion in the region in particular the skiing. By itself, it has become an object of interest to tourists. One year later, the first ski arrived in the area of the Arlberg pass (to Langen am Arlberg). In 1900 the first stage of the Flexenstrasse from Langen to Lech was completed, and in 1908 from Lech to the border of Tyrol, thus creating a reasonable transport condition for the Tannberg region and the Arlberg Pass. The less demanding first customers enjoyed quickly organized private accommodations.

The refuges occurred as well. The first one was founded in 1885 (Konstanzer Hut), in 1889 (Darmstaedter Hut), in 1903 (Ulmer Hut) in St. Anton area. In 1897 the stylish Hotel Post was opened. Alpine leisure culture has continued to improve by raising the standard of accommodation and the number of tourist facilities. The long, compact village, shaped by massive slopes, that descended into the Rosanna River Valley was filled with series of straight, compact solids covered with gable roofs, referring to a rural lapidary settlement. Homogeneous colors: white of plaster, brown of wood dominated the silhouette.

In 1937 the cable car Galzig Cable Car was established, which inaugurated a new era.

A typical Alpine architecture like hotel building, reproducing earlier patterns, in the exuberant version regarding size, décor, and solutions characteristic of the architecture of the holiday was continued.

The World Alpine Ski Championships in 2001 motivated Sankt Anton am Arlberg to reorganize. The route of the railway changed. A service and recreation center filled with open greenery in an unconstrained form occupied the remaining vacant space after railway. Freely, albeit deliberately, sprawling lawns, ponds, streams, paths and small architecture are the substitutes of the immense nature surrounding the resort. Park is unfortunately not a version of the alpine garden, but it shows the priority of space management. Innovative glass and steel productions such as the Galzigbahn and Rendlbahn lower stations and contemporary cubicles with sports and hotel functions are emerging, referring, in a sense, 
to local solutions. However, contact with nature is the decisive factor of the limits of development.

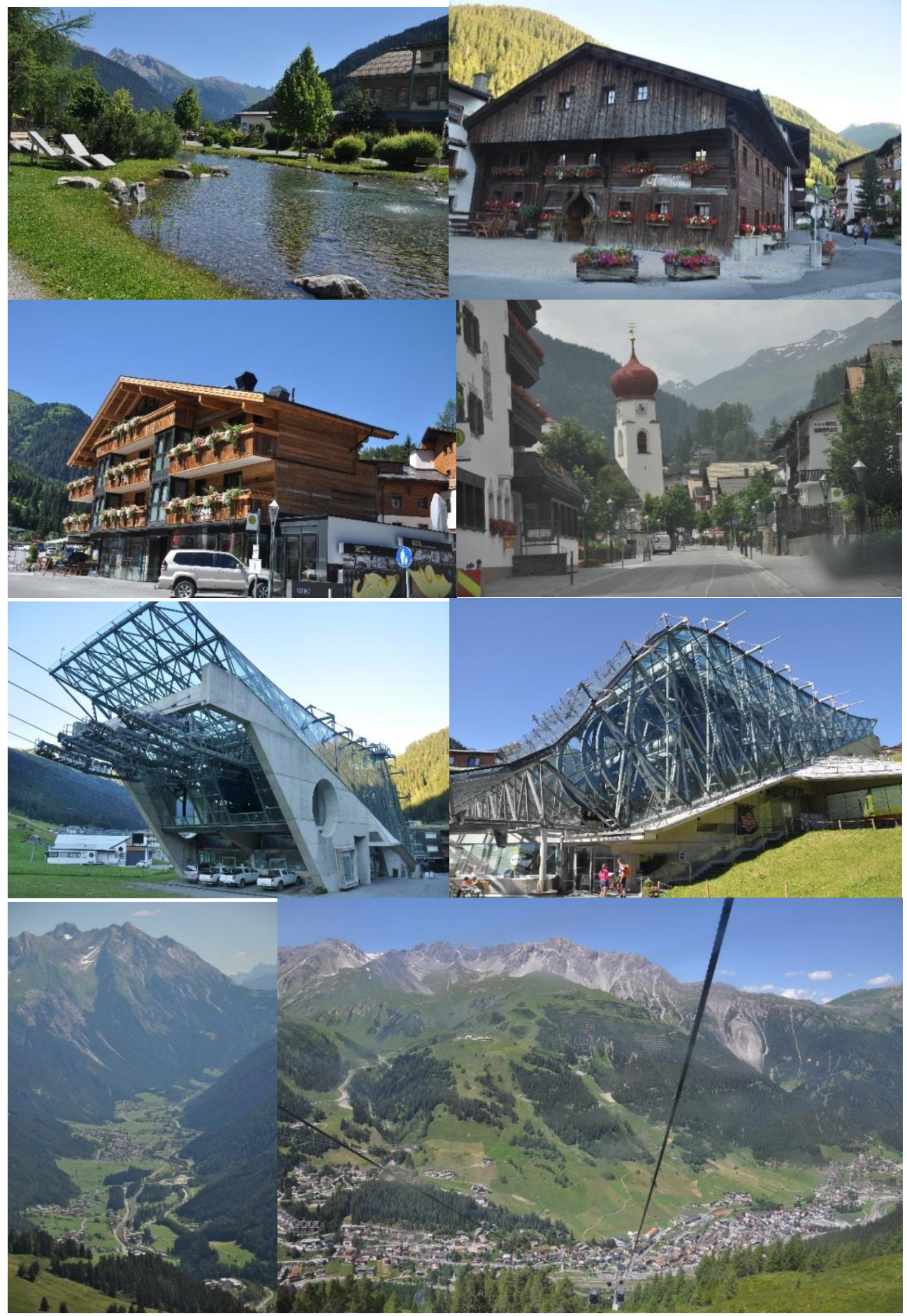

Fig. 3. St. Anton am Arlberg 2016 (photos by author). 
The sensation is that there are villages which have not lost their agricultural function and character, despite having tourist and sports functions such as St. Jakob, Pettneu, Schnann, Flirsch - near St. Anton and in the neighboring Grosses Walsertal area: Zug, Raggal, Sonntag, Blons, Damüls. The region that formerly had been relying on agriculture balanced the economy - by tourism and sport.

\section{Summary}

At the same time a favorable economic situation occurred in different mountain regions. The aspirations of people, business, art, engineering, industry have opened up the natural environment, creating new quality there. Among the mountainous regions, the resorts that try to maintain moderate influence on the environment are particularly prominent. Perhaps it was determined by the historical, visual, health, and the ambition reasons. The untouched landscape is peculiar today.

Semmering is an example of a luxury resort - a health resort. It has succeeded in saving the historic urban layout, the architecture of the turn of the century and nature, which once became the precursor to the uprising of the village. The newly built ski station adheres to the premise of more than a century, without breaking the boundaries of the established order. The older part, despite its unique character, seems to be struggling with the problems of maintaining age-related building tissue. Perhaps the revival of open sports areas (fashionable as before and now) could turn out to be the solution to the isolated Semmering? There are many opportunities in this unspoiled natural environment.

Otherwise St. Anton am Arlberg, with its rural roots, flourishes by introducing modern infrastructure and changing the ruralist layout. In this courageous action, however, the focus on moderation is noticeable. Is the role of nature - its topography, that blocks the growth of the town or the intentional spatial policy? At this stage, the effect is optimal. The right proportions are maintained between modernity and tradition, building and dominating nature.

Szklarska Poręba, having become the spa resort and the city at some point, architecturally resembles Semmering. Also, the natural environment approaches the two towns to each other. Szklarska Poreba is, however, a much larger settlement unit than Semmering. So in the case of Szklarska Poręba, it is worthwhile to use the experience of Semmering and St. Antone.

Historical relations between the mass of greenery and the mass of cubes, as well as the former distance between buildings, especially in residential areas, should be preserved.

It is advisable to recognize composition systems, including viewpoints and incorporate them into planning new developments.

It is indispensable to protect the natural vegetation and land relief, appropriate only for the Karkonosze, also in the vicinity of the nearest buildings.

New housing enclaves ought to create coherent, individual urban layout separated by green.

It is worth deciding the planned scale of the city, reasonable boundaries, and character. The city consists of varied areas: remote settlements such as Orle, Jakuszyce and deserted areas of forests, meadows, mountain peaks of the Jizera Mountains and the Karkonosze, part of the Karkonoski National Park with Kamieńczyk Waterfall and Szrenica Mountain. Jakuszyce settlement is a troublemaking place. Is it worth spending this unspoiled place on the Szklarska Pass to create the second St. Anton? With the achievements of St. Anton can undoubtedly benefit from the organization of a sports facilities in the center of Szklarska Poręba - the base of ski lifts, accompanied by chaotic and unattractive development.

Certainly, the revitalization and use of historical, large-scale buildings from the former glassworks, neatly integrated into a difficult terrain topography, in the central part of the city would have been a sensation compared to the ostensible tourist attractions. 
Perhaps it is much more problematical to improve and adapt the existing state to changing values than to continuous development and building.

The turn of the nineteenth and twentieth centuries, the time of the birth of the described towns, was defined as a time of great longing. Among other things, this was a longing for the past. Hopefully, the arguments presented here do not fit into the worthless reflection that may accompany the next turn of the twentieth and twenty-first centuries.

\section{References}

1. M. Falser, https://edoc.hu-berlin.de/handle/18452/7696, 2 (2005)

2. S. Dettling, T.Bernhard, Tracks, 16 (2014)

3. S. Dettling, T.Bernhard, Tracks, 14 (2014)

4. S. Dettling, T.Bernhard, Tracks, 143 (2014)

5. I. Łaborewicz, P.Wiater. Szklarska Poręba monografia historyczna, 426 (2011)

6. P. Jakubec, L. Jirásek, J. Kafka, J. Kašpar, I. Łaborewicz, I. Navrátil, M. Pavlisová, J. Pažoutová, R. Reil, E. Tomková, P. Zahradnik, Schroniska turystyczne Karkonoszy $i$ Gór Izerskich $w$ Polsce oraz w Czechach, 18 (2015)

7. B. Szymanski-Störtkuhl, J. Ilkosz, Wspaniały krajobraz artyści i kolonie artystyczne w Karkonoszach $w$ XX wieku, 112 (1999)

8. D. Vasko-Juhász, Die Südbahn ihre Kurorte und Hotels, 86 (2006) 